\title{
A Concise History of the Middle East, 8th ed.
}

\author{
Arthur Goldschmidt Jr. and Lawrence Davidson
}

Boulder, Colorado: Westview Press, 2006. 559 pages.

In a discipline rich in studies addressing the multifarious aspects of the Middle East, a publication exploring the region's history from the pre-Islamic period to the present confronts a fervent contest in establishing itself as a notable work. As the authors of A Concise History of the Middle East indicate from the outset, the challenge of conveying the relevance of past events to contemporary affairs is both complex yet essential. For Arthur Goldschmidt Jr. and Lawrence Davidson, the course is well-worn, as their publication enters its eighth edition since 1979. With a plethora of maps depicting the transitory regional borders dating from the Byzantine period to the present day, alongside cogent depictions of the Hashemite lineage and the Ottoman sultans and a piquant narrative, Goldschmidt and Davidson provide an account that proves - although directed toward undergraduate students and neophytes to the Middle East - a satisfying meander through regional triumphs and despairs over the course of twenty-one chapters.

Consigned as "a dreary bore, a dead subject suited only to cranks, antique-lovers, or perhaps a few students seeking bits of small talk with which to impress their peers" (p. 2), the authors grapple with the waning allure of history in contemporary society in their introduction. Aware of the limitations, the opening chapter strives to rouse the reader with a swift assessment of the Middle East's global contributions to language, religion, philosophy, mathematics, and science. Avoiding the plaintive plea to comprehend the origins of the current conflicts, the authors combine drollness with facts to ensure that the narrative does not falter and reiterate poignant questions throughout the publication, such as: "As Americans, who may at times 
question the political attitudes and actions of Middle Eastern peoples, let us ask ourselves ... When did we last fight a war on U.S. soil? When did we last experience a foreign military occupation?" (p. 2).

Advancing into chapter 2, "The Middle East before Muhammad," a charismatic and informative account of the early era is delivered through a straightforward narrative suited to the target readership. Chapters 3 and 4, "The Prophet of Mecca" and "What Is Islam?" respectively, afford veritable mines of information complimented by isolated boxes of text giving brief biographies of the major figures. However, just as the ability to cover the vast expanse of Islamic history within a relatively few pages constitutes a significant merit, as is common with such publications, it also confronts the dilemma of space versus content, rendering the publication limited if it is to be utilized by readers seeking an exhaustive analysis of a specific subject area.

The ensuing chapters gather pace as "The Early Arab Conquests," "The High Caliphate," and "Shi is and Turks, Crusaders and Mongols" are surveyed through chapters 5,6 , and 7 , respectively. As the focus shifts to Islamic civilization, the authors strive to remedy cultural misconceptions, lauding the survival and transmission to the West of the works of Plato, Aristotle, and other Greek thinkers. Equally, the quandary of adapting "a religion based on adherence to a divinely sanctioned code of conduct ... in a world in which many of its nation-states and leading minds no longer believe in God" (p. 113) is addressed, as well as the political, legal, theological, and spiritual divisions that are rife in the region.

Chapter 8, "Firearms, Slaves, and Empires," romps through the Mamluks' victory over the Mongols in 1260 to the defeated Ottoman Empire's surrender of Hungary to Habsburg Austria in 1699. The worthy assessment is coupled by a tree depicting the Ottoman sultans from 1280-1922 and a compelling account of the Buddhist presence in the region, initially espoused by the Il-Khanids until the transition to Islam during the rule of Ghazan Khan (r. 1295-1304).

Despite its diminutive size, chapter 10, "European Interests and Imperialism," charts the relationship between Europe and the Middle East within an equal number of pages. Encompassing a vast breadth of issues, including the changes wrought on the trade routes by the European presence and Napoleon's arrival in 1798, the Ottoman Empire's decline is engagingly portrayed. Attributing this to the debauchery nurtured by "the charms of the harem, dulled by wine or hashish, [and] hamstrung by janissary revolts" (p. 158), additional culpability is assigned to nepotism, superstition, and megalomania on the part of "rapacious landlords and tax-farmers" (p. 159) who served to realize the Turkish maxim balik baçdan kokar (the fish stinks from 
the head). Nevertheless, the accomplishments of such reforming sultans as Osman II (r. 1618-22), Murad IV (r. 1623-40), and the Koprulu family, to name but a few, are equally extolled.

The succinct portrayal of the dichotomy between Islam and nationalism is swiftly succeeded by chapter 13: "The Roots of Arab Bitterness." One of the book's finest chapters, the shrewd measures undertaken by the British and French governments in the post-war region are objectively recounted and developed further in chapter 16, "The Contest for Palestine," and chapter 17, "Israel's Rebirth and the Rise of Arab Nationalism." With the idiosyncrasies harbored by each side aligned seamlessly with the profiles of the protagonists, the chapter dryly concludes with I. F. Stone's theory that "if God is dead, he died trying to solve the Arab-Israeli conflict" (p. 290). In addition to the Palestine-Israel conflict, the ensuing chapters assess the Iranian revolution, the Gulf War, and the current war on terrorism.

Regrettably, the publication falls victim to the very pitfall it expounds: "Any historian who writes a textbook that includes the recent past walks on eggs. ... Projections are hazardous. Who knows what a future reader will see as having been the major Middle Eastern events from 2000 to 2005?" (p. 421). Accordingly, acclaim for Jordan's prowess in averting terrorism ruefully contrasts with the events of November 2005. Equally, the bearing of Hamas' victory and the ensuing clashes, Sharon's decline, the 2006 Lebanon war, and the bungled execution of Saddam, each of which resounded on the region's development, remain inopportunely absent. Nevertheless, A Concise History of the Middle East remains a valuable resource for students embarking on preliminary studies of the region and a worthy contribution to the field of Middle Eastern history.

K. Luisa Gandolfo

Ph.D. Candidate, Institute of Arab and Islamic Studies University of Exeter, United Kingdom 